\title{
MODEL OF JAVELIN THROWING LEARNING FOR SMK STUDENTS
}

\author{
*Ana Laela, Samsuddin, dan Hernawan
}

\begin{abstract}
Correspondence: Physical Education, Postgraduate, Jakarta State University
E-mail: analaela1@gmail.com
\end{abstract}

\begin{abstract}
The aim of the study was to produce and develop a javelin learning model for SMK students. This research uses the method of Research and Development $(R \& D)$ of Borg and Gall, the subject of this research and development is the student/I SMK Negeri 2 Rangkas Bitung. In limited trials (small group trials) use subjects 20 students/I and a large group trial using 40 subjects while the effectiveness test was using the 40 subjects. In the test of the effectiveness of learning models using the instrument assessment instruments how to hold the javelin, prefix attitude, throwing movements, the final attitude/recovery using rubric/portfolio (Process Assessment). Analysis of the data in this study using test$T$, the results of the initial test before given the treatment of a javelin learning model amounting to 52.93 then after giving the treatment of the learning model in javelin increased to 89.90. In the test of significance differences with application.
\end{abstract}

\section{Keywords: Learning Model, javelin throw}

\section{Introduction}

Education is a process of learning the knowledge, skills, and habits of a group of people passed down from the generation to generation through teaching, training, and research. With education, one can have Keserdasan, noble morality, personality, power of spritual, and skills that benefit oneself and society. Education can also build one's own ideas and emotions continuously, so that changes in human consciousness that also relentlessly give significant character to the education process. The quality of education is certainly not separated from the teaching process and learning outcomes that start from basic education to secondary education.

Physical education is one of the subjects given on a particular school level which is one of the education of physical activity and healthy life coaching. The goal of physical education, exercise and health is to improve skills and mobility basis. The basic motion here in question is The basic motion here in question is Includes roads, runs, jumping and throwing. According to Winarno (2007:82) it states that "physical, sports and health education aims to help students develop, both physically, mentally, and socially. It is what distinguishes physical, sports and health education with other subjects " (Winarno, 2007:82) (Winarno \& Surendra, 2016).

PJKR

https://jurnal.unimed.ac.id/2012/index.php/jpehr 
Physical education is a medium to promote physical growth, psychic development, motor skills, knowledge and reasoning, and the awareness of values and healthy lifestyle habituation to stimulate the growth and development of balanced physical and psychic qualities. The motion is designed in the right situation, in order to stimulate students ' growth and development optimally(Himawan Aprilian Linggar Prasetya, 2013)

The goal of physical education in schools is to develop self-management skills in the development and maintenance of physical fitness and healthy lifestyles through physical activities and exercise. Husdarta (2009 : 76), said that physical education is an integral part of the overall education program, as one aspect of education in secondary school, physical education, sports and Health (PJOK) aims to develop cognitive, affective and psychomotor spheres. The purpose of physical education is not only physical development but also mental, social, and moral (Husdarta, 2009 : 76) (Adi Prastyo Kurniawan, 2016).

Javelin throwing is an athletic learning branch which is generally less desirable by students/I, it is seen from the lack of enthusiastic students/I in the following lessons. The lack of enthusiastic student/I is caused by several factors, one of which is the use of a pretty creepy javelin with a very pointed tip, made of iron that creates a sense of misgivings the student/I when doing so. Another factor is the presentation of material that is less varied so as to cause the students to lazy in following it. Athletic learning is only introduced in some cases or formalities in the process, after which the learning is continued with other activities such as the learning of football as a favorite learner.

The observation and observation of researchers at the time of athletic learning, especially the students'javelin numbers are less enthusiastic in following the study, both son and daughter students. This situation makes the problem of how to learn how javelin throwing can increase learning outcomes. Because with such circumstances, the purpose of learning is unlikely to be achieved, after observation, this is due to the monotonous learning or learning that is oriented only on theoretical learning Without using a learning model in material presentation Learning. The tools used are also very minimal, so teachers must be able to develop learning models by modifying the tools in order to run the student learning process well and the results of learning can also be achieved.

There are problems and reasons above, hence the researcher concluded that it is necessary to develop learning model that will give positive in creating an active learning atmosphere. The learning Model also provides convenience to the physical education teachers to deliver learning materials to students. Overcoming the problems above, through a varied and interesting learning model will make the learning atmosphere more active and give a sense of passion for learning. So that students are active and passionate about learning, and enriching experience of learners ' movements and knowledge, which will make the results of this research become one of the teaching materials to improve teaching learning process 
especially javelin. Thus can be concluded very in need of learning Model javelin throwing for SMK students.

\section{Research Method}

The concept of developed model is a development of learning media to improve javelin throwing skills through modifications with target media targets are varied. Motede The research that became the benchmark was the Borg and Gal development model. Following the steps of the Borg and Gall learning model are:

1) Research and information collecting, in this step, among others, literature studies relating to the issues studied, measurement needs, research on a small scale, and preparation for Formulating research frameworks.

2) Planning, in this step devise a research plan related to the problem, and determine the objectives to be achieved.

3) Develop preliminary form of product, that is, develop the form of Fermulaan of the product to be produced. Examples, learning materials development, learning processes and evaluation instruments.

4) Preliminary field testing, which is conducting the initial field test on a limited scale with the number of 20-40 subjects.

5) Main product revision, that is to make improvements to the original product produced based on the results of the initial test.

6) Main field testing, usually called the main test that involves a wider audience with a number of subjects 20 to 60 people.

7) Operational product revision, which is improving the results of the test more broadly, so that the product developed is already a design operational model that is ready to be validated.

8) Operational field testing, the validation test step to the operational model that has been produced. Involving 20 to 60 subjects.

9) Final product revision, which is to make final repairs to the model developed to produce the final product (final).

10) Dissemination and implementation, which is the step of disseminating products/models developed to the public Especially in the educational scene.

Like the statement Ali Maksum (2012: H. 29) states that "The trial aims to (1) to know if the design of the model has been properly applied and correct by the teacher, (2) How effective is the outcome of applying the model to the purpose of this research" (Ali Maksum, 2012: H. 29). Thus, a quantitative approach was used to seek such effectiveness with pre-experimental design of the one group Pretest-posttest design that is as follows: 
Table 1. Research desain in the model effectiveness test

\begin{tabular}{|c|c|c|c|}
\hline Subject & Pres-Test & Treatment & Post-Test \\
\hline $\mathrm{R}$ & $\mathrm{O} 1$ & $\mathrm{P}$ & $\mathrm{O} 2$ \\
\hline
\end{tabular}

The steps performed in this trial include; (1) Establish the research subject group; (2) Implement pre-Test (O1); (3) tried the model that has been developed; (4) Implementing post-Test (O2); (5) Look for the average pre-test and post-test scores and compare between the two; (6) Looking for the difference of the second average distinction through the method statistic (test-T) to understand whether there is a significant influence of the use of learning models, a formula for processing data with test subjects using uji-t procedures and using the SPSS application, to get pre-test and post-test results.

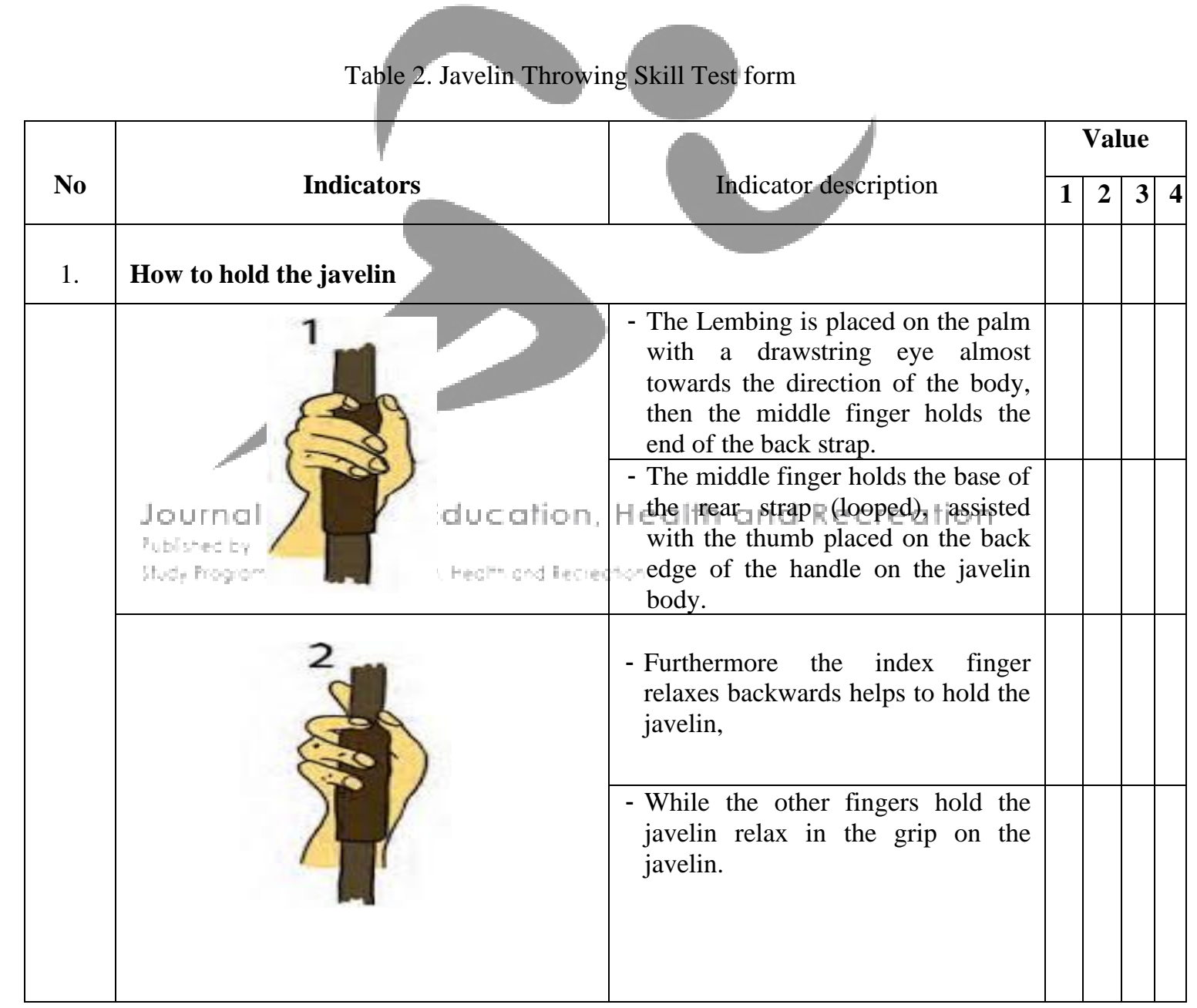




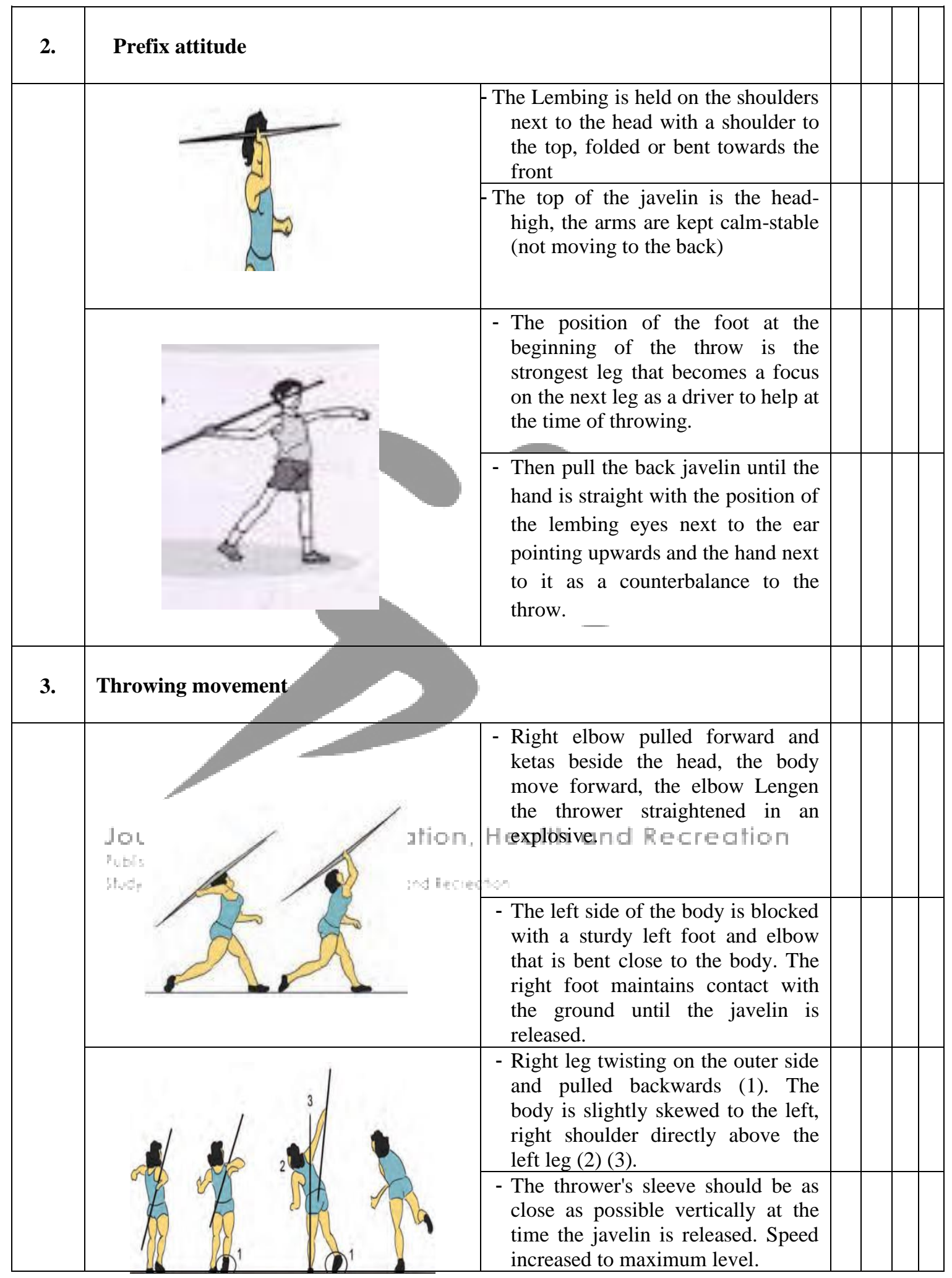




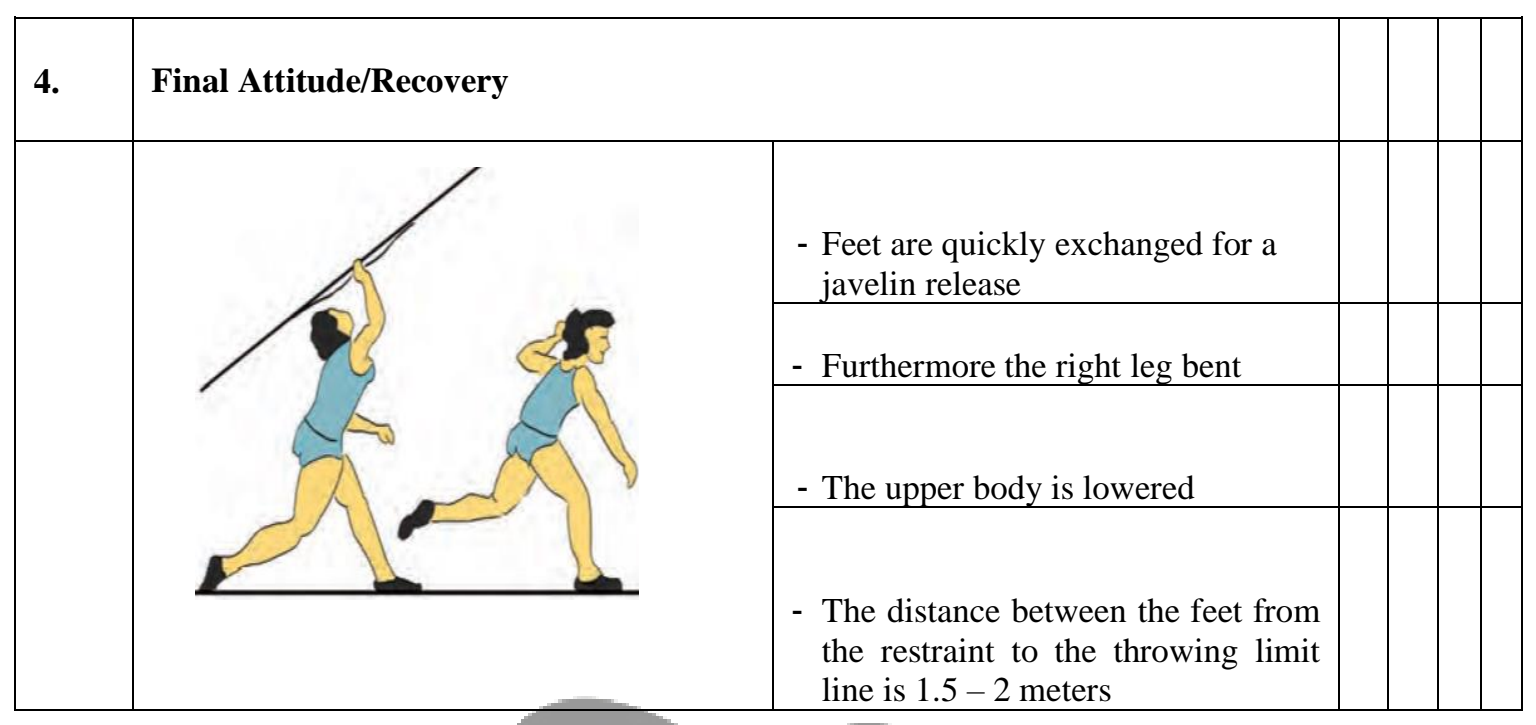

Table 3. Javelin Throwing Instrument Assessment

\begin{tabular}{|c|c|c|}
\hline A. & Aim & $\begin{array}{l}\text { This test aims to measure javelin throwing skills for the students/I high } \\
\text { school nursing (SMK) }\end{array}$ \\
\hline $\mathrm{B}$ & $\begin{array}{l}\text { Tools and } \\
\text { Facilities }\end{array}$ & \begin{tabular}{l|l|} 
1. Bullet modification & 4. Stationery \\
2. Whistle & 5. Field \\
3. Score Sheet & \\
\end{tabular} \\
\hline $\mathrm{C}$ & Judge (Teachers) & $\begin{array}{l}\text { Three people (teachers): Observe and give a score based on the } \\
\text { provisions of each jevelin trowing process }\end{array}$ \\
\hline $\mathrm{D}$ & $\begin{array}{l}\text { Test } \\
\text { Implementation } \\
\text { Journal P } \\
\text { Pubrestit }\end{array}$ & $\begin{array}{l}\text { 1. Students are gathered and explained } \\
\text { 2. students to warm up for } 15 \text { minutes in coordination } \\
\text { 3. Studen conduct exprements by being called one by one. } \\
\text { 4. Javelin is modification given to each student. } \\
\text { 5. Each student has twice the Opportunity to experiment with } 2 \\
\text { repetitions, in the first and second selections which are considered to } \\
\text { be the basic technique of javelin }\end{array}$ \\
\hline $\mathrm{E}$ & Rating Rating & Based on the instrument \\
\hline & \multicolumn{2}{|c|}{$\begin{array}{l}\text { How to score and to throw javelin scoring criteria } \\
\text { a. Initial attitude scoring criteria: } \\
\text { A value of } 4 \text { if all gesture attitudes can be performed correctly. } \\
\text { A value of } 3 \text { if more than } 4 \text { gesture attitudes can be performed correctly. } \\
\text { A value of } 2 \text { if more than } 2 \text { gesture attitudes can be performed correctly. } \\
\text { A value of } 1 \text { if all gesture attitudes cannot be performed correctly } \\
\text { b. Throwing attitude scoring criteria: } \\
\text { A value of } 4 \text {, if all gesture attitudes can be performed correctly. } \\
\text { A value of } 3 \text {, if more than } 4 \text { gesture movements are performed correctly. } \\
\text { A value of } 2 \text {, if more than } 2 \text { gesture attitudes are performed correctly. } \\
\text { A value of } 1 \text { if all gesture attitudes are not possible correctly. } \\
\text { c. The criticism of the attitude release assessment of Javelin: } \\
\text { A value } 4 \text { If all gesture attitudes can be done correctly. } \\
\text { A value of } 3 \text { if more than } 2 \text { gesture attitudes can be performed correctly. }\end{array}$} \\
\hline
\end{tabular}

PJKR_

https://jurnal.unimed.ac.id/2012/index.php/jpehr 
A value of 2 if more than 1 gesture attitude can be done correctly.

A value of 1 if all gesture attitudes are not possible correctly.

d. Critical assessment of the posture after throwing:

A value of 4 if all gesture attitudes can be performed correctly.

A value of 3 if more than 2 gesture attitudes can be performed correctly.

A value of 2 if more than 1 gesture attitude can be performed correctly.

A value of 1 if all gesture attitudes cannot be performed correctly.

$\mathrm{NA}=\frac{\text { The total score obtained }}{\text { Maksimum number of score }} \quad$ X 100

Impormation : NA = Final score

\section{Results and Discussion}

After a small group trial and revision of the second stage of the model development product component of the Javelin learning, followed by field trials and third stage revision of model development product components Learning to throw javelin, then to know the average effectiveness of products, carried out the implementation process with the collection of effective test data using $\mathrm{T}$ test with SPSS software. Product trial conducted by 40 students.

Tabel 4. Pre-Test and Post-test results for the effectiveness of the javelin Throwing learning Model for SMK students

\begin{tabular}{|c|c|c|c|}
\hline \multirow{2}{*}{ No } & \multirow{2}{*}{ Name } & \multicolumn{2}{|c|}{ Javelin Throw } \\
\hline & & Pre Test & Post Test \\
\hline 1 & Subject 1 & 53 & 87 \\
\hline 2 & Subject 2 & 51 & 86 \\
\hline 3 & Subject 3 & 55 & 90 \\
\hline purtal i & Subject4l Educatid & n. He54th an & d Rec85atiol \\
\hline 5 & Subject 5 & 52 & 88 \\
\hline 6 & Subject 6 & 49 & 85 \\
\hline 7 & Subject 7 & 55 & 89 \\
\hline 8 & Subject 8 & 52 & 87 \\
\hline 9 & Subject 9 & 58 & 92 \\
\hline 10 & Subject 10 & 58 & 89 \\
\hline 11 & Subject 11 & 52 & 86 \\
\hline 12 & Subject 12 & 55 & 90 \\
\hline 13 & Subject 13 & 55 & 89 \\
\hline 14 & Subject 14 & 54 & 92 \\
\hline 15 & Subject 15 & 55 & 88 \\
\hline 16 & Subject 16 & 54 & 87 \\
\hline
\end{tabular}

PJKR_

https://jurnal.unimed.ac.id/2012/index.php/jpehr 


\begin{tabular}{|c|c|c|c|}
\hline \multirow{2}{*}{ No } & \multirow{2}{*}{ Name } & \multicolumn{2}{|c|}{ Javelin Throw } \\
\hline & & Pre Test & Post Test \\
\hline 17 & Subject 17 & 58 & 93 \\
\hline 18 & Subject 18 & 51 & 90 \\
\hline 19 & Subject 19 & 52 & 91 \\
\hline 20 & Subject 20 & 50 & 88 \\
\hline 21 & Subject 21 & 53 & 87 \\
\hline 22 & Subject 22 & 50 & 89 \\
\hline 23 & Subject 23 & 54 & 90 \\
\hline 24 & Subject 24 & 54 & 92 \\
\hline 25 & Subject 25 & 51 & 90 \\
\hline 26 & Subject 26 & 49 & 89 \\
\hline 27 & Subject 27 & 50 & 87 \\
\hline 28 & Subject 28 & 49 & 88 \\
\hline 29 & Subject 29 & 51 & 90 \\
\hline 30 & Subject 30 & 58 & 91 \\
\hline 31 & Subject 31 & 49 & 89 \\
\hline 32 & Subject 32 & 54 & 86 \\
\hline 33 & Subject 33 & 54 & 88 \\
\hline 34 & Subject 34 & 50 & 88 \\
\hline 35 & Subject 35 & 54 & 90 \\
\hline 36 & Subject 36 & 55 & 90 \\
\hline 37 & Subject 37 & 50 & 89 \\
\hline our 38 al & Subjeet 38 Ed & He $59_{\text {th }}$ & Rec92ation \\
\hline$=-39$ & Subject 39 & 50 & 89 \\
\hline 40 & Subject 40 & 50 & 90 \\
\hline & Avaerage value & 52.93 & 89.90 \\
\hline
\end{tabular}

The above has been shown a table of average results of test pre test and post Test learning bullet-reject style backstroke. Test pre test done after large group test. Pre test is done before implementing 10 models of javelin throwing learning. The average results of a javelin-throwing learning test are 52.93. After being given treatment with 12 models of the study of Bullet reject style backstroke, done post test or final Test and the average value of post test is 89.90 . Based on the above explanation, the result of the data after being calculated on the IBM SPSS Statistic application. The following results are displayed after 
calculating Paired Sample Statistic, Paired Sample Correlations,dan Paired Sample Test.

Tabel 5. Paired Samples Statistics

\begin{tabular}{|c|c|c|c|c|c|}
\hline \multicolumn{2}{|c|}{} & Mean & N & $\begin{array}{c}\text { Std. } \\
\text { Deviation }\end{array}$ & $\begin{array}{c}\text { Std. Error } \\
\text { Mean }\end{array}$ \\
\hline \multirow{2}{*}{ Pair 1 } & Pre Test & 52.9250 & 40 & 2.84098 & .44920 \\
\cline { 2 - 7 } & Post Test & 88.9000 & 40 & 1.98456 & .31379 \\
\hline
\end{tabular}

From the explanation above, it can be concluded that generally the summary results of descriptive statistics before given treatment with the data study model pre-test shows from 40 subjects obtained Mean 52.93, Std. Deviation 2,840 and STD. Error Mean 449. After given product treatment model that was developed post-test data show from 40 subject obtained Mean 89.90 Std. Deviation 1.984 dan Std. Error Mean 313. Mean the average value of the javelin throwing defected is increasing.

Tabel 6. Paired Samples Correlations

\begin{tabular}{|c|c|c|c|c|}
\hline & & $\mathrm{N}$ & $\begin{array}{c}\text { Correlati } \\
\text { on }\end{array}$ & Sig. \\
\hline $\begin{array}{l}\text { Pair } \\
1\end{array}$ & $\begin{array}{l}\text { Pre Test \& } \\
\text { Post Test }\end{array}$ & 40 & .444 & .004 \\
\hline
\end{tabular}

The correlation result or the relationship between the two data variable pre-test and post-test shows from 40 subjects earning value correlatiaons 444 .

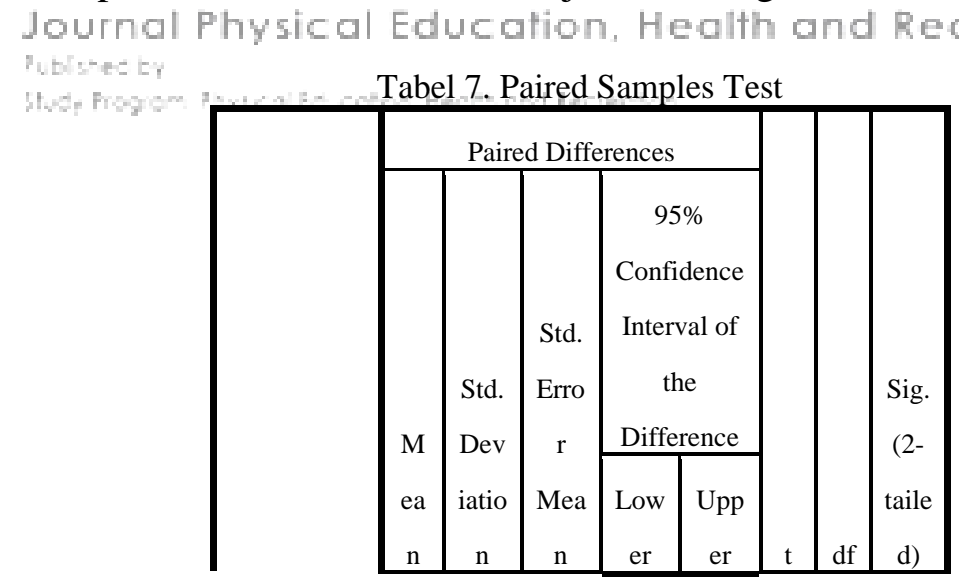




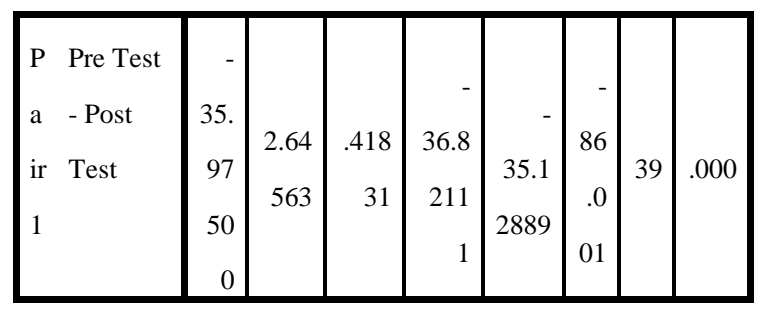

In test of significance differences with application SPSS Statistic obtained T-count result-86,001 and Sig. (2-tailed) $0.00<0.05$ which means there is a significant difference in the model of javelin throwing learning for SMK students before and after given Learning model treatment of javelin throwing. Based on the information, it can be concluded that there is a significant and effective pedation and can improve the learning results of javelin throwing for SMK students.

In the course of a study, there are supporting factors and barriers in implementation. Of course, it is also experienced by researchers, some supporting factors experienced during conducting research include:

1. The guidance and direction given by the advisers in conducting research is very helpful researchers in completing the study of the javelin throwing learning model.

2. In conducting the research process, researchers feel full support by the students/I SMK as well as the teacher of the Penjas and athletic academic lectures.

3. The selection of the right experts and have a spare time to discuss the variety of models developed is very helpful in the process of implementing the research. model is:

A factor that is considered as a bottlennod in the development of this

1. Because the Covid-19 virus Development learning model of javelin throwing becomes the main obstacle In the development of this model.

2. Development using network communication (online) is also a barrier in the development of this model so that researchers must be extra patient in delivering the material so that students easily understand it.

3. The difficulty factor of the signal and the student/I do not have a quate and weather that cannot be predicted like rain sometimes becomes an obstacle to doing the learning.

\section{Conclusion}

Based on the data obtained, from small group trials and trials of large groups and field trials and discussion of research results can be concluded that:

1. With this learning model of javelin throwing students will be easier to apply and do learning effectively and efficiently.

2. With the learning model materials that researchers developed, students/I will be able to understand the material well and implement the practice skillfully 


\section{References}

Adi Prastyo Kurniawan, S. C. Y. H. (2016). Application of Learning Models with Play Approaches to Enhancing Basic Motion Skills in Learning Physical Education, Sports and Health. Journal of Sports and Health Education, 04, $148-156$.

Himawan Aprilian Linggar Prasetya, T. R. Ustiadi \& M. A. (2013). Development of "Dodge Ball" Soccer Dribbling and Passing Game Models in 2012. Journal of Physical Education, Sport, Health and Recreations, 2 (8).

Winarno, R. F. S. M. E., \& Surendra, M. (2016). Basic Technical Learning Model for Reject Sideways Style Bullets. Journal of Physical Education, Vol 26 No. 1 April 2016, 26, 176-186.

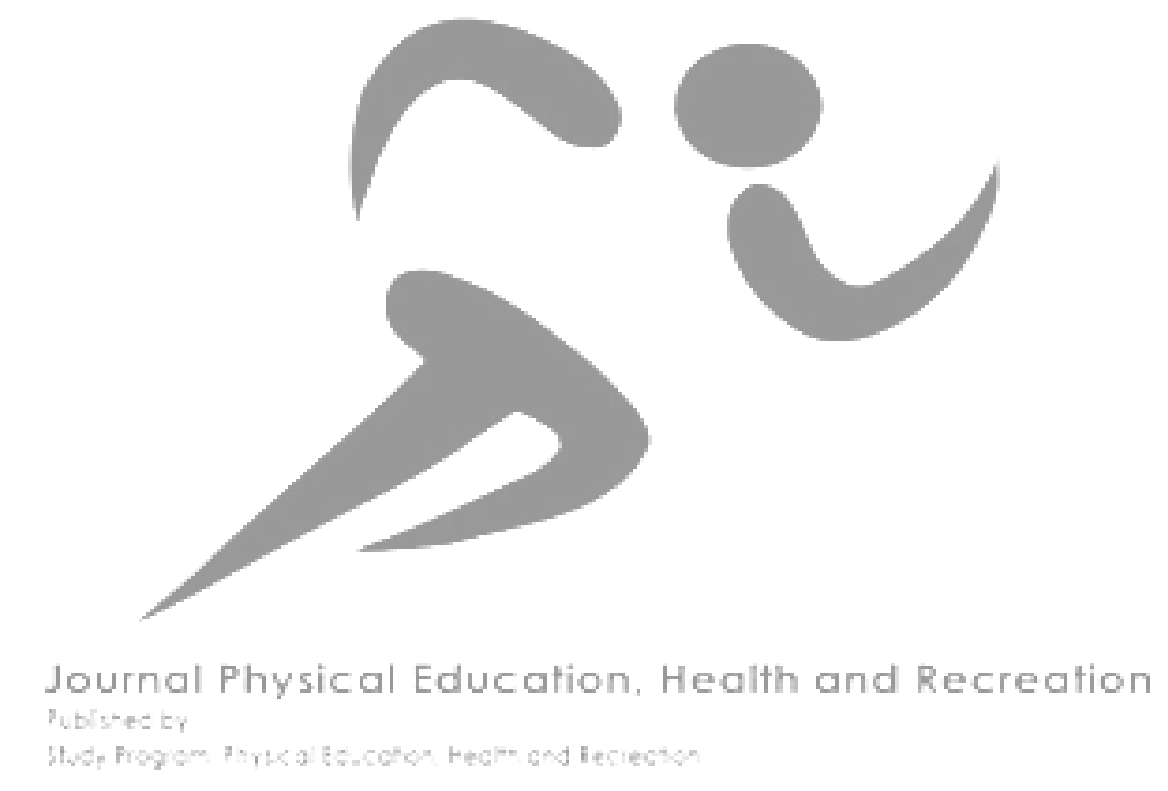

